\title{
George Derek Musgrove, Rumor, Repression, and Racial Politics: How the Harassment of Black Elected Officials Shaped Post-Civil Rights America
}

Christopher E. Manning

Loyola University Chicago, cmannin@luc.edu

Follow this and additional works at: https://ecommons.luc.edu/history_facpubs

Part of the History Commons

\section{Author Manuscript}

This is a pre-publication author manuscript of the final, published article.

\section{Recommended Citation}

Manning, Christopher E.. George Derek Musgrove, Rumor, Repression, and Racial Politics: How the Harassment of Black Elected Officials Shaped Post-Civil Rights America. The American Historical Review, 118, 2: , 2013. Retrieved from Loyola eCommons, History: Faculty Publications and Other Works, http://dx.doi.org/10.1093/ahr/118.2.551

This Book Review is brought to you for free and open access by the Faculty Publications and Other Works by Department at Loyola eCommons. It has been accepted for inclusion in History: Faculty Publications and Other Works by an authorized administrator of Loyola eCommons. For more information, please contact ecommons@luc.edu.

\section{(c) (i) $\ominus$}

This work is licensed under a Creative Commons Attribution-Noncommercial-No Derivative Works 3.0 License. (c) 2013 Oxford University Press 
George Derek Musgrove, Rumor, Repression, and Racial Politics: How the Harassment of Black Elected Officials Shaped Post-Civil Rights America. (Since 1970: Histories of Contemporary America.) Athens: University of Georgia Press. 2012. Pp. xiii, 296. Cloth $\$ 69.95$, paper $\$ 24.95$.

Barack Obama's first presidential term bore witness to an enhanced scrutiny of the presidency that frequently exhibited traces of historic racism towards African Americans-a phenomenon that shocked many politicians, pundits and the press. While recent manifestations of racism within American politics are distressing, one could also argue that its rejection by large segments of the population points to how far we have come. In Rumor, Repression, and Racial Politics Derek Musgrove reveals that a disturbing pattern of aggressive behavior towards black elected officials dates back to the Voting Rights Act of 1965 (VRA). Musgrove argues that black allegations of government harassment, at the local and federal levels, were more than mere conspiracy theory; rather widespread harassment did occur between 1965 and 1992 and that persecution profoundly affected black Americans' perception of the media and the state (p. 2).

Musgrove's introduction summarizes the transformation of black protest leadership to black electoral leadership, with the number of black elected officials rising from 280 in 1965 to 9,040 by 2000. White Democratic forces in the Deep South responded by harassing black officials. When Richard Nixon took office, the federal government joined in what had been locally based processes. Ironically, Nixon's impeachment and the distrust generated from Watergate led to a pattern of increased scrutiny on all elected officials by the media and internal government watchdog agencies, but African American politicians received particular attention.

Musgrove's borrows from from Peter Knight, when he argues that following the late 1960s Americans embraced "a new conspiracism"-“a willingness to entertain conspiratorial explanations for political events coupled with a deep suspicion of government that made such explanations appear plausible" (p. 7). Simultaneously, Americans refashioned the term "conspiracy theory" to its current pejorative meaning, which allowed opponents to dismiss African American politicians' accusations against the government (p. 9). Meanwhile conspiracy became a way for African American politicians to comprehend the apparent harassment that they experienced (p. 11).

Chapter 1, "The White Backlash and the Roots of Harassment Ideology, 19651968" argues that the effort of the Georgia statehouse and the United States Congress to block the seating of state representative Julian Bond and congressman Adam Clayton Powell Jr. evidenced the evolution of black political participation, the offsetting power of "white backlash," and the emergence of two distinctly different perspectives, one black one white, on the surveillance and investigation of black office-holders (p. 14-15). While Musgrove's description of Bond's case, in which the Georgia statehouse blocked Bond's seating because of his criticisms of the Vietnam War, is an excellent example of white backlash and resistance, his description of Powell's circumstances is confounded somewhat by Powell's poor behavior within the context of often poorly behaving colleagues.

Chapter 2 argues that the prevalence of state repression and surveillance in the late 1960s occurred as a result of the displacement of white political forces throughout 
the country, especially in the Deep South, and the Nixon administration continued this pattern as it used agencies such as the Federal Bureau of Investigation and the Internal Revenue Services, to batter Democratic officials and push for a Republican realignment of national politics. Musgrove argues that the advancement and expansion of black politics in this time period resulted from black power ideology, which made it immediately suspect to local and national government watchdog agencies. This argument is somewhat problematic, since the roots of black electoral efforts in the South date back far earlier than the black power era. 1960s era notions of black power simply expressed the most recent version of it. Nevertheless, increased government suspicion is apparent and Musgrove provides a laundry list of unethical state efforts in the Deep South to resist increases in black electoral power (p. 49-54). Surveillance and harassment then went to a higher level under the Nixon administration when he put "increased pressure on the intelligence community to expand federal surveillance and counterintelligence of dissident groups and political opponents." These efforts included surveillance of twelve out of thirteen members of the Congressional Black Caucus at the time (p. 64, 66-69).

Chapter Three traces the evolution of thought among African American electoral officials that recently elected black politicians did indeed experience racially motivated surveillance and investigation. Mary Sawyer, acting under the sponsorship California lieutenant governor George Brown, found extensive evidence of widespread surveillance and harassment of black political officials and published her findings in Dilemma. The research conducted for Dilemma lead to the foundation of the Center for the Study of Black Leadership and widespread acceptance of Sawyer's ideas by black politicians. Yet the emerging anti-harassment ideology did not acknowledge the guilt of some African American politicians nor did it contextualize African American experiences within the general increased scrutiny and investigation of all elected officials (p. 75, 76, 83). Methodologically, Dilemma defined harassment vaguely, excluded the perspectives of government officials, and accepted without proof the notion "of a single national or international conspiracy" (p. 95-97).

Musgrove's most striking material comes in Chapter Four, "Prosecution as Political Warfare in the Reagan and Bush Years, 1981-1992." Here Musgrove argues that even though efforts to crack down on corruption in public office were framed as disinterested public service, they were carried out by ideologically motivated Republican partisans who used harassment to transform the political makeup of the nation in favor of the GOP, with black political leaders (often Reagan's harshest critics) receiving a disproportionate brunt of the attack (p. 109). Musgrove charts the expansion of the usage of "official corruption" in political warfare between the two parties. The Reagan administrations executed 803 prosecutions of federal officials in 1991, the highest number on record (p. 112). African American officials, who made up only three percent of all elected officials, were targeted for fourteen percent of Department of Justice (DOJ) official corruption cases (p. 118). Complaints by black representatives led to a series of hearings in the House Judiciary Committee, which found that the FBI initiated "sting" operations against black officials based only on rumors. Once a sting began, however, the FBI ignored procedural safeguards and went after suspects with dogged determination until they cracked (125-128).

Musgrove brings his focus to one state in Chapter Five, "Selective Prosecution in Alabama." He argues here that a wave of black political empowerment grew in reaction 
to the Reagan offensive and that while local white conservatives utilized state and federal apparatuses to investigate black politicians in a biased manner, black Alabamians fought their opponents to a stalemate that lasted until the onset of the Clinton administration ( $\mathrm{p}$. 145-147, 177-179). At first blacks concentrated on raising the number of registered voters, while whites successfully countered with increased usage of absentee ballots. The DOJ refused to investigate black allegations of voter fraud and suggested that blacks learn to use absentee ballots with same way as their opponents. This strategy succeeded, but white conservatives countered with allegations of voter fraud that were then pursued by local law enforcement (p. 147-151). By 1984 court cases allowed for DOJ intervention and local white conservatives convinced them to execute joint investigations of black political empowerment efforts with local authorities. At first these investigations discouraged black voter participation, but black elected officials quickly rallied with effective legal defense strategies and even greater voter registration efforts (p. 151-159).

The counteroffensive reached its peak between 1987 and 1989, with several large protests, raised awareness, fundraising campaigns and a new report by Sawyer that possessed all of the same mistakes of the first and more; this report did not note widening federal involvement in investigations (p. 181-189). This greater consciousness and determination led to the establishment of the Center for the Study of African Americans in 1990, but its establishment came at a time when government investigations were declining. Nevertheless, the 1990 trial of Marion Barry raised the anti-harassment ideology to its zenith, but the fact that Barry received support from the black community despite his apparent personal failings revealed the failings of the anti-harassment conceptual framework (p. 192-196).

Musgrove concludes that despite its flaws, the decline of government harassment of black elected officials, and heightened investigation of Republican officials under the Clinton administrations, anti-harassment ideology retains currency among black elected officials. Today political warfare includes not only investigations of officials, but also greater usage of multiple forms of the media and voter suppression campaigns. These circumstances, he argues, all tie back to the conservative backlash against newly elected black officials (p. 11, 214). In this way, black experiences of harassment in the twentieth century portended the partisan gridlock that characterizes American politics today.

Christopher Manning

Loyola University, Chicago 